\title{
The Role of Fiscal Policy in a Monetary Union: are National Automatic Stabilizers Effective?
}

\author{
Andrea Colciago* \\ University of Milano-Bicocca
}

\author{
V. Anton Muscatelli \\ Heriot-Watt University \\ and CESifo, Munich
}

\author{
Tiziano Ropele \\ Bank of Italy
}

\author{
Patrizio Tirelli \\ University of Milano-Bicocca
}

\begin{abstract}
We assess the role of national fiscal policies, as automatic stabilizers, within a monetary union. We use a two-country New Keynesian DSGE model, incorporating non Ricardian consumers and a home bias in national consumption. Fiscal policy directly stabilizes non Ricardian agents' consumption. By doing so it contributes to the reduction in the volatility of variables such as output, wage inflation and real interest rates. Our analysis of country-specific shocks does not suggest potential inter-country conflicts (as long as policies are constrained within the automatic stabilizers framework). However, we detect a potential conflict between the two consumers groups, because fiscal policy may raise optimizing agents' consumption volatility.
\end{abstract}

JEL Classification: E58, E62, E63

We thank Helge Berger, Menzie Chinn, Thomas Moutos, Alessandro Missale and other participants to CESifo-Delphi Conference "Global Economic Imbalances, Prospect and Remedies" and to the first Piero Moncasca Money-Macro Meeting at the University of Pavia for useful comments and suggestions. The views expressed herein are those of the authors and do not necessarily reflect those of the Bank of Italy. The usual disclaimer applies.

* Corresponding author. Address: Dipartimento di Economia Politica, Università di Milano Bicocca, Piazza dell'Ateneo Nuovo, 20126, Milano. E-mail: andrea.colciago@unimib.it. 


\section{Introduction}

There is a general consensus that national fiscal policies should play an enhanced role in adjusting to macroeconomic shocks within EMU. According to the 'Brussels view', the ECB alone should stabilize the union-wide economy, and automatic stabilizers should take care of within-EMU differences (Buti et al., 1998, 2001). We examine the validity of this latter proposition and assess the performance of fiscal stabilizers in a two-country New Keynesian model of a monetary union. Our contribution on the role of national fiscal policies is closely related to the ongoing debate on the design of fiscal policy within the constraints of the Stability and Growth Pact (SGP, henceforth). Our model accounts for a greater number of fiscal policy transmission channels than usually found in New Keynesian models. For instance, we introduce a distortionary payroll tax that affects marginal costs and inflation. Second, we introduce rule-of-thumb or non Ricardian consumers (RT, henceforth), as in Galí et al. (2004) and (2007), Bilbiie (2005) and Muscatelli et al. ( 2003b). The standard forward-looking IS curve is driven by Ricardian consumers who consume on the basis of the permanent income hypothesis. This is in contrast with the empirical evidence provided, inter alia, by Campbell and Mankiw (1989) which suggests that current consumption equals current income for a significant proportion of consumers. RT consumers cannot access financial markets and hence are constrained to consume out of current disposable income. Limited participation in financial markets introduces an important channel through which fiscal policy can operate. In fact, following a shock, Ricardian agents can smooth consumption by adjusting savings and the accumulation of physical capital. This opportunity is precluded to RT consumers, whose consumption pattern would instead benefit from temporary fiscal transfers and from fiscal policies designed to stabilize labour incomes. Notice that both distortionary taxation and the RT consumers assumption break the Ricardian equivalence proposition.

The formation of EMU and the development of the New Open Economy Macro literature has spurred new interest in the role of fiscal policy and its interactions with monetary policy (see 
Coutinho (2005) for a recent survey). Galí and Monacelli (2005) analyze optimal fiscal policy in a monetary union characterized by a large number of small countries. To maintain analytical tractability they neglect capital accumulation and maintain a Ricardian environment. Ferrero (2005) considers a two-country DSGE model with distortionary taxation, but abstracts from capital accumulation and RT consumers. We see a radically different role for fiscal policy, which can be used to enable consumption smoothing of RT agents. Furthermore, in contrast with standard open economy models, the introduction of RT agents allows to characterize a monetary union where only a limited proportion of the population can benefit from international risk sharing. This is consistent with empirical evidence suggesting that risk sharing in Europe is still limited, albeit rising over the last ten years (Kalemli-Ozcan et al. (2004)).

Our findings can be summarized as follows. Firstly, we demonstrate that, regarding the union as a single economy, the union-wide fiscal policy helps reducing variability of the main macroeconomic variables in the aftermath of a union-wide shock. Thus, the union-wide fiscal policy can effectively complement monetary policy as a stabilization tool. The main operational channel works through the impact of automatic stabilizers on the disposable income of RT consumers. Secondly, we consider a variety of country-specific shocks to the monetary union. We find that simple fiscal rules have stabilizing effects in both countries. Thirdly, we obtain some unexpected results concerning debt control, a controversial issue in the EU context. Controlling debt-to-GDP ratio of the whole union is crucial to obtain stability, and the symmetric working of automatic stabilizers in each country is sufficient to ensure a unique rational expectations equilibrium. Moreover, when the share of Ricardian consumers in the two countries is not too small, strong control of national differences in the accumulation of debt leads to indeterminacy of the rational expectation equilibrium. Our results suggest a novel approach to the philosophy of EMU macroeconomic policymaking. Although a rule-based approach is probably necessary to discipline national fiscal policies (see Beetsma and Debrun (2004) and Canzoneri et al. (2002) for a discussion on the presence of a public spending bias in a DSGE model of EMU), such rules should be carefully designed to ensure equilibrium de- 
terminacy. The 'keep-your-own-house-in-order' approach underlying the SGP should, perhaps, be replaced with a new emphasis on the control of aggregate debt in the union and on the need to pursue national fiscal policies which are symmetrical over the business cycle. Furthermore, in sharp contrast with the 'Brussels consensus', automatic stabilizers should play a role, not only as a surrogate for the loss of nominal exchange rate flexibility, but also as a useful complement to the ECB actions. In fact our results show that while monetary policy alone is relatively effective at controlling the volatility of variables such as output and inflation, it can only indirectly affect consumption of RT consumers. This happens because RT households do not react to interest rates. In this regard fiscal policy directly stabilizes RT consumption. So doing, it also contributes to the reduction in the volatility of variables such as output, wage inflation and real interest rates. Our analysis of countryspecific shocks does not suggest potential inter-country conflicts (as long as policies are constrained within the automatic stabilizers framework). However, we detect a potential conflict between the two consumers groups, as in some cases fiscal policy raises optimizing agents' consumption volatility.

\section{A Two-country New Keynesian Model}

The monetary union consists of two symmetrical countries, which we refer to as the Home $(\mathrm{H})$ and Foreign $(\mathrm{F})$ country. Population size is normalized to one at the union level. Variables relative to country $\mathrm{F}$ are denoted with a superscript asterisk. To economize on space we present only the equations relative to the home economy.

We use a dynamic stochastic general equilibrium model, in many aspects akin to Christiano et al. (2005) and Schmitt-Grohé and Uribe (2005). The model accounts for both nominal and real rigidities. The former are characterized as sluggish adjustment of prices and wages. The latter originate from internal habit formation in consumption, monopolistic competition in factors and goods markets, adjustment costs in investment and capacity utilization. In addition, as in Galí et al. (2004, 2007), we impose that a fraction of households are constrained to consume out of current income. Within-Union interactions are modelled as follows: all goods are traded, each country specializes in 
a subset of consumption goods, the law of one price holds throughout, and consumers exhibit a preference bias towards domestically produced goods. Thus, in our model the purchasing power parity does not hold.

Households. In each country there is a fraction $\vartheta$ of non Ricardian consumers. Variables relative to Ricardian and non Ricardian households are denoted with superscript ' $o$ ' and ' $r t$ ', respectively. Households preferences are defined in terms of consumption of a composite good, $c_{t}$, and labour, $h_{t}$, and are described by the following intertemporal utility function:

$$
E_{0} \sum_{t=0}^{\infty} \beta^{t}\left[\exp \left(\varepsilon_{t}^{c}\right) \ln \left(c_{t}^{i}-b c_{t-1}^{i}\right)-\exp \left(\varepsilon_{t}^{h}\right) \phi_{0} \frac{h_{t}^{1+\varphi}}{1+\varphi}\right]
$$

for $i=o, r t$. $\beta$ represents the subjective discount factor, $\mathrm{b}$ denotes internal habit formation in consumption and $\varphi$ denotes elasticity of marginal disutility of labor. The composite consumption good is defined as $c_{t}=\left[\chi^{1 / \eta} c_{H, t}^{(\eta-1) / \eta}+(1-\chi)^{1 / \eta} c_{F, t}^{(\eta-1) / \eta}\right]^{\eta /(\eta-1)}$, where $c_{H, t}$ and $c_{F, t}$ are themselves constructed as aggregators of domestic and foreign differentiated goods. ${ }^{1}$ The parameter $0.5<\chi<1$ captures idiosyncratic taste or home bias, while $\eta>1$ measures the elasticity of substitution between foreign and domestic goods. Optimal allocation of expenditure yields the following demand functions

$$
c_{H, t}=\chi\left(\frac{P_{H, t}}{P_{t}}\right)^{-\eta} c_{t} \text { and } c_{F, t}=(1-\chi)\left(\frac{P_{F, t}}{P_{t}}\right)^{-\eta} c_{t}
$$

where $P_{t}=\left[\chi P_{H, t}^{1-\eta}+(1-\chi) P_{F, t}^{1-\eta}\right]^{1 /(1-\eta)}$ defines the consumer price index. Finally, two shocks affect households' utility: a consumption preference shock, $\varepsilon_{t}^{c}$, and a labour disutility shock, $\varepsilon_{t}^{h}$. Both shocks obey a first-order autoregressive process with parameters $\rho^{c}$ and $\rho^{h}$, respectively.

Ricardian Households. In each country, the representative optimizing household makes a sequence

\footnotetext{
1 Optimal allocation of expenditure within each category of goods results in standard demand functions, i.e., $c_{H, t}(z)=2\left[P_{H, t}(z) / P_{H, t}\right]^{-\theta_{p}} c_{H, t}$ and $c_{F, t}(z)=2\left[P_{F, t}(z) / P_{F, t}\right]^{-\theta_{p}} c_{F, t}$. National producer price indexes are given by $P_{H, t}=\left[2 \int_{0}^{0.5} P_{H, t}(z)^{1-\theta_{p}} d z\right]^{1 /\left(1-\theta_{p}\right)}$ and $P_{F, t}=\left[2 \int_{0.5}^{1} P_{F, t}(z)^{1-\theta_{p}} d z\right]^{1 /\left(1-\theta_{p}\right)}$, where $\theta_{p}>1$ is the elasticity of substitution across goods.
} 
of decisions. First, it makes a consumption/saving decision. Second, it decides portfolio allocation over physical capital and riskless financial assets, also negotiating contingent claims traded across the Union (as in Galí and Monacelli (2005)). Simultaneously, it chooses how many units of capital services to provide. Third, it supplies labour on demand, given the wage negotiated by monopolistic unions (see below). The nominal flow budget constraint is given by

$$
\frac{x_{t+1}}{1+R_{t}}+P_{t}\left(c_{t}^{o}+i_{t}^{o}\right)=x_{t}+A_{t}+\left[r_{t}^{k} u_{t}-a\left(u_{t}\right)\right] P_{t} k_{t}^{o}+h_{t}^{d} W_{t}+P_{t}\left(\phi_{t}-\tau_{t}\right)
$$

where $h_{t}^{d} W_{t}$ denotes nominal labour income, $A_{t}$ is the nominal net cash flow from participating in the union-wide state-contingent security market and $\phi_{t}$ represents firms' real profits. $X_{t}$ denotes holdings of riskless nominal bonds issued by home and foreign government, which are perfect substitutes. $R_{t}$ is the nominal interest rate on bond issued at time $t$ and $\tau_{t}$ defines real lump-sum taxes. As pointed out above, optimizing households own the physical stock of capital $k_{t}^{o}$, and rent it to firms at the real rental rate $r_{t}^{k}{ }^{2}$ Furthermore, owners of physical capital control the degree of its utilization, $u_{t}$. The term $a_{t}\left(u_{t}\right) \equiv \gamma_{1}\left(u_{t}-1\right)+0.5 \gamma_{2}\left(u_{t}-1\right)^{2}$ defines the real cost of using the capital stock with intensity $u_{t}$. As in Christiano et al. (2005) and Schmitt-Grohé and Uribe (2005), the capital stock evolves according to: $k_{t+1}^{o}=(1-\delta) k_{t}^{o}+i_{t}^{o}\left[1-S\left(i_{t}^{o} / i_{t-1}^{o}\right)\right]$, where the parameter $\delta$ denotes the depreciation rate and $S\left(i_{t}^{o} / i_{t-1}^{o}\right)=0.5 \kappa\left(i_{t}^{o} / i_{t-1}^{o}-1\right)^{2}$ accounts for investment adjustment costs.

Non Ricardian Households. In each period RT households consume their current income: $P_{t} c_{t}^{r t}=h_{t}^{d} W_{t}-P_{t} \tau_{t}$. Again, notice that in our set up consumers delegate wage decisions to the unions and therefore also RT households supply labour to meet firms' labour demand.

Firms. Each differentiated good $z$ is produced with a Cobb-Douglas technology function:

$$
y_{t}(z)=\exp \left(\varepsilon_{t}^{a}\right)\left[k_{t}(z)\right]^{\alpha}\left[h_{t}(z)\right]^{1-\alpha}
$$

where $\alpha$ is the steady state share of income which goes to capital and the productivity shock $\varepsilon_{t}^{a}$

\footnotetext{
${ }^{2}$ We assume that households only hold capital used by domestically located firms.
} 
obeys a first-order autoregressive process. $k_{t}(z)$ denotes time $t$ capital service, while $h_{t}(z)$ represents the amount of labour input, which is a composite of differentiated labour services provided by domestic households. The real marginal cost, common across producers, is given by:

$$
m c_{t}=\frac{\exp \left(-\varepsilon_{t}^{a}\right)}{\alpha^{\alpha}(1-\alpha)^{(1-\alpha)}}\left(\frac{P_{t} t_{t}^{p r}+W_{t}}{P_{H, t}}\right)^{1-\alpha}\left(\frac{R_{t}^{k}}{P_{H, t}}\right)^{\alpha}
$$

where $W_{t}=\left[2 \int_{0}^{0.5} W_{j, t}^{1-\theta_{w}} d j\right]^{1 /\left(1-\theta_{w}\right)}$ defines the minimum nominal cost of purchasing one unit of the domestic composite labour input $h_{t}=\left[2^{1 / \theta_{w}} \int_{0}^{0.5} h_{j, t}^{\left(\theta_{w}-1\right) / \theta_{w}} d j\right]^{\theta_{w} /\left(\theta_{w}-1\right)}$. The pay-roll tax for each unit of $h_{t}$ hired is represented by $P_{t} t_{t}^{p r}$. The pay-roll tax introduces a distortionary wedge between the wage outlays and labour costs. Firm's z optimal demand of labour type j is $h_{j, t}(z)=2\left(W_{j, t} / W_{t}\right)^{-\theta_{w}} h_{t}(z)$, where $\theta_{w}$ represents the elasticity of substitution across labor types.

We model nominal rigidities following the mechanism spelled out in Christiano et al. (2005). In each period firms have a probability $1-\xi_{p}$ to optimally adjust their nominal price. Non adjusting firms fully index their price to the previous period domestic producer price inflation as follows: $P_{H, t}(z)=\pi_{H, t-1} P_{H, t-1}(z)$, where $\pi_{H, t-1}=P_{H, t-1} / P_{H, t-2}$. The optimal price, $\tilde{P}_{H, t}$, chosen to maximize the discounted sum of future expected profits subject to the demand constraint, fulfils

$$
\frac{\tilde{P}_{H, t}}{P_{H, t}}=\frac{\theta_{p}}{\theta_{p}-1} \exp \left(\varepsilon_{t}^{p}\right) \frac{E_{t} \sum_{j=0}^{\infty}\left(\beta \xi_{p}\right)^{j} P_{t+j}^{\theta_{p}} y_{t+j}^{d} \lambda_{t+j}^{o}\left(\frac{P_{H, t+j-1}}{P_{H, t-1}}\right)^{-\theta_{p}} \frac{P_{H, t+j}}{P_{H, t}} m c_{t+j}}{E_{t} \sum_{j=0}^{\infty}\left(\beta \xi_{p}\right)^{j} P_{t+j}^{\theta_{p}} y_{t+j}^{d} \lambda_{t+j}^{o}\left(\frac{P_{H, t+j-1}}{P_{H, t-1}}\right)^{1-\theta_{p}}}
$$

where $\lambda_{t}^{o}$ represents Ricardian households' marginal utility of income and $y_{t}^{d}$ is the aggregate demand. Equation (3) suggests that adjusting firms set prices as a mark-up over a weighted average of future expected marginal costs. As in Galì (2003), we also assume that the optimal price is subject to a cost push shock, $\varepsilon_{t}^{p}$, which follows a first order autoregressive process with coefficient $\rho^{p}$. $^{3}$

\footnotetext{
${ }^{3}$ Upon log-linearization and aggregation, the FOC for price setting translate into the standard New Keynesian Phillips
} 
Labour Market. In each country there is a continuum of size 0.5 of differentiated labour inputs indexed by $j$. As in Schmitt-Grohé and Uribe (2005) household $i$ supplies all country-specific labor inputs. Labor-type specific unions set nominal wages taking as given firms' labor demand. Following Galí et al. (2007), we assume that agents are uniformly distributed across unions. ${ }^{4}$ Once the union has determined $W_{j, t}$, agent $i$ stands ready to supply as many hours as required by firms. However, the total number of hours allocated to the different labour markets must satisfy the time resource constraint $h_{t}^{i}=\int_{0}^{0.5} h_{j, t} d j$ for $i=r t, o$. Aggregate demand for labour input $j$ is $h_{j, t}=2\left(W_{j, t} / W_{t}\right)^{-\theta_{w}} h_{t}^{d}$, where $h_{t}^{d}$ represents aggregate labour demand. ${ }^{5}$ Combining the latter expression with the time constraint provided above yields $h_{j, t}=2 h_{t}^{d} \int_{0}^{0.5}\left(W_{j, t} / W_{t}\right)^{-\theta_{w}} d j$. Since labour effort does not depend on any household-specific variable, residents in one country (Ricardian and non Ricardian) work for the same amount of time which we denote $h_{t}$.

We model nominal wage rigidity as follows. In each period unions face a constant probability $1-\xi_{w}$ to optimally set the nominal wage. Non-adjusting unions index their wages to lagged consumer price inflation according to the rule $W_{j, t}=\pi_{t-1} W_{j, t-1}$, where $\pi_{t-1}=P_{t-1} / P_{t-2}$. As in Colciago (2006), the optimal nominal wage chosen at time $t$ maximizes a weighted average of agents' lifetime utilities. The weights attached to the utilities of Ricardian and non Ricardian agents are (1- $)$ and $\vartheta$, respectively. Notice that although RT consumers cannot plan for the future, unions act on their behalf and set the optimal wage taking into account their future welfare.

Government. In each period the government consumes an amount $g_{t}$ of the domestically-produced composite good. We assume that the government minimize the cost of producing $g_{t}$, as a result public expenditure for each variety is $g_{t}(z)=2\left(P_{H, t}(z) / P_{H, t}\right)^{-\theta_{P}} g_{t}$. Government flow real budget con- 
straint reads as: $d_{t+1}=\frac{\left(1+R_{t}\right)}{\pi_{t+1}} d_{t}+g_{t}-T_{t}^{p r}-\tau_{t}$, where $T_{t}^{p r}=t_{t}^{p r} h_{t}$ denotes total proceedings from the payroll tax and $d_{t}$ is the outstanding level of debt.

Market Clearing. The clearing of the market for final goods requires $y_{t}(z)=2\left(P_{H, t}(z) / P_{H, t}\right)^{-\theta p} y_{t}^{d}$ for all $z \in[0,1]$, where aggregate demand reads as $y_{t}^{d}=c_{H, t}+c_{H, t}^{*}+g_{t}+i_{t}+a\left(u_{t}\right) k_{t}$. Here, $c_{H, t}^{*}$ denotes foreign demand of the home produced composite good. The clearing condition of the market for capital requires $u_{t} k_{t}=\int_{0}^{0.5} k_{t}(z) d z$ where $k_{t}=(1-\vartheta) k_{t}^{o}$ is the aggregate stock of physical capital.

\section{Policy rules}

Interest rate rule. We assume that monetary policy follows an inertial Taylor rule specification:

$$
\frac{R_{t}}{R}=\left(\frac{R_{t-1}}{R}\right)^{\phi_{3}} E_{t}\left(\pi_{t+1}^{E U}\right)^{\phi_{1}}\left(\frac{y_{t}^{E U}}{y^{E U}}\right)^{\phi_{2}}
$$

Variables without time subscripts identify steady-state values. The union-wide consumer price inflation and aggregate output are $\pi_{t}^{E U} \equiv\left(\pi_{t} \times \pi_{t}^{*}\right)^{0.5}$ and $y_{t}^{E U} \equiv\left(y_{t} \times y_{t}^{*}\right)^{0.5}$, respectively. This monetary policy setting provides us with a benchmark to assess the performance of different specifications for automatic fiscal stabilizers.

Fiscal Rules. We consider a simple feed-back format for our fiscal policy rules:

$$
\begin{gathered}
\frac{g_{t}}{g}=\left(\frac{y_{t}}{y}\right)^{-\delta_{1}}\left(\frac{d_{t-1}}{y}\right)^{-\delta_{2}} \\
\frac{\tau_{t}}{\tau}=\left[\frac{y_{t}(z)}{y}\right]^{\varphi_{1}}\left[\frac{d_{t-1}(z)}{y}\right]^{\varphi_{2}} \text { and } \frac{T_{t}^{p r}}{T^{p r}}=\left[\frac{y_{t}(z)}{y}\right]^{\varphi_{1}}\left[\frac{d_{t-1}(z)}{y}\right]^{\varphi_{2}}
\end{gathered}
$$

This follows, inter alia, Van Den Noord (2000), Westaway (2003) and Andres and Domenech (2005). Our taxation rule imposes the same adjustment pattern on both taxes, and does not look at how a mix of tax measures might improve the design of policy. ${ }^{6}$ Our fiscal rules are largely captur-

\footnotetext{
${ }^{6}$ Andres and Domenech (2005) provide an analysis of how different tax measures might impact on output and inflation variability.
} 
ing automatic stabilizers through the output gap terms and, as discussed above, feature a feedback from real debt accumulation, as implicitly required by the SGP. The fiscal tools have a differentiated impact on the economy. Government spending directly impacts on aggregate demand, indirectly affecting disposable income of RT consumers. Personal taxation has a direct effect on RT households' consumption, while the payroll tax impacts on the labour cost wedge. This affects inflation, the real wage and labour demand.

\section{Calibration}

As in Backus et al. (1994) and Chari et al. (2002), we set the degree of substitutability between bundles of goods produced at home and abroad, i.e., $\eta$, to 1.5. Each country features the same degree of home bias equal to 0.7. Following Galì et al (2004) and Muscatelli et al. (2005) we set the fraction of RT consumers equal to 0.5 . The output-share of government purchase is 20 percent and steady state debt-to-GDP ratio is set to 60 percent. The payroll tax is calibrated to be 10 percent of steady state total labour cost. Steady state personal taxes are then determined as to balance steady state government budget. Finally, we define the fiscal feedback coefficients. For our baseline case we select $\delta_{1}=\varphi_{1}=0.5, \delta_{2}=\varphi_{2}=0.05$. A coefficient of 0.5 on output is consistent with the empirical evidence in Van Den Noord (2000) and adopted in studies on fiscal stabilization (e.g. Westaway (2003)). Remaining parameters are displayed in Table 1 . The reader can refer to Christiano et al (2005) for empirical evidence supporting them.

\section{Designing Fiscal Policy in a Monetary Union}

We now examine the extent to which national fiscal policies can assist with macroeconomic adjustment in EMU. The key issues we address are: do automatic stabilizers actually assist the ECB's function of stabilizing output and inflation in the union, and in individual countries, i.e. do the fiscal authorities assist or impede the efforts of the ECB? Which fiscal instruments are more effective in stabilizing the union and the individual economies? How do the stabilization properties of fiscal policy vary in response to different structural shocks? 
We consider the following four policy scenarios: ${ }^{7}$ 1) the ECB operates its policy rule (7), but automatic stabilizers are kept switched off (labelled M ); 2) only the government spending rule (8) is switched on together with the monetary policy rule (labelled $M+G$ ); 3) only the government taxation rules (9) are switched on together with the monetary policy rule (labelled M+T); and 4) where both fiscal rules (8)-(9) are switched on together with the monetary policy rule (labelled M+G+T). Our evaluation of the alternative policy rules will focus on variables directly related to households' welfare, such as consumption patterns, worked hours and the dynamics of consumer price and wage inflation.

Results modelling the Union as a single country. Before turning to our full two-country model, we focus on the dynamic performance of the monetary union as a single country. In practice, this involves aggregating across all optimizing and RT households in the two economies, assuming that wage and price settings are unified across the union, shocks are symmetric, and that there are two policymakers: the central bank and a single union-wide fiscal authority. We follow common practice and solve the model taking a log-linear approximation around the deterministic zero inflation steady state. ${ }^{8}$

Equilibrium determinacy obtains in our baseline calibration, which accounts for interest rate inertia. ${ }^{9}$ We simulate the closed-economy version of our model following each of the four shocks outlined in the section above: a cost-push shock $\left(\varepsilon_{t}^{p}\right)$, a demand (preferences shock) $\left(\varepsilon_{t}^{c}\right)$, a technology shock $\left(\varepsilon_{t}^{a}\right)$, and a labor disutility shock $\left(\varepsilon_{t}^{h}\right)$. We set the autoregressive parameters equal to 0.5 . Figures 1-4 report the impulse response functions under three of the four policy scenarios discussed above. Policy scenario 2, featuring government expenditure switched on alongside monetary policy, is not shown to avoid excessive cluttering of the graphs.

The role of automatic stabilizers is briefly sketched as follows. RT consumers are financially con-

\footnotetext{
${ }^{7}$ In all cases the fiscal feedbacks on debt are activated to offset the impact of monetary policy on debt service payments.

${ }^{8}$ The model is numerically solved using DYNARE.

${ }^{9}$ Recent works on determinacy of New Keynesian DSGE models have shown that the presence of RT consumers may require deviations from the Taylor principle (Galí et al. (2004); Bilbiie (2005)). Colciago (2006) shows the Taylor principle is restored when a moderate degree of wage stickiness is added to the model.
} 
strained and require fiscal policy to help reducing consumption volatility. In fact, taxation affects RT consumers' disposable income. This occurs both through the direct effect of lump-sum taxes on disposable income and through the impact of the payroll tax on inflation. The latter effect is beneficial for the real wage. In contrast, government expenditure only has an indirect effect on RT agents' consumption, by marginally stabilizing output. It is interesting to note that, by stabilizing demand, the fiscal rules also have a beneficial effect on worked hours. In turn, a stable marginal rate of substitution between labour and consumption contributes to dampen the volatility of wage inflation. ${ }^{10}$ In Figure 1 we see that optimizing consumers increase their consumption in response to a cost-push shock. This is due to the response of the real interest rate, which falls on impact. By contrast there is an initial decline in consumption of RT agents, who cannot smooth consumption adjusting investment and capacity utilization, and therefore suffer from the strong adverse effect of inflation on the real wage. Relative to the remaining three shocks, in this case automatic stabilizers play a limited role. This happens for two reasons. Firstly, taxes target total output, which is less sensitive to the shock than consumption of RT agents. Secondly, the direct impact of the cost push on inflation overwhelms the dampening role of the payroll tax on the labour cost wedge. ${ }^{11}$

Turning to Figure 2, we see that the demand (preference) shock directly raises consumption of optimizing households. In addition, the shock raises the relative preference for consumption for any given level of labour effort. As a result wage inflation falls. This, in turn, has a (moderate) negative effect on inflation and stimulates labour demand. Consequently, disposable income and thus consumption of RT agents increases. Fiscal policy has no significant impact on optimizing consumers, but stabilizes RT households' consumption. Inflation volatility is almost unaffected. Observe that only during the first periods fiscal policy has a dampening effect on consumption of RT consumers, which rises again after a few quarters. This happens because, after the initial fall, the recovery of wage inflation is relatively sharp, strongly increasing disposable incomes.

A positive technology shock increases investment and the capital stock, and raises optimizing con-

\footnotetext{
${ }^{10}$ See Erceg and Levine (2001) on the welfare effects of wage inflation stabilization.
} 
sumers' expenditure over the long capital accumulation cycle (Figure 3). Consumer price inflation falls with marginal costs. The output gap response is negative due to price stickiness and to the inertial monetary policy. ${ }^{12}$ Wage inflation and worked hours consequently fall, determining a reduction in RT consumers' disposable income. Fiscal policy has a strong beneficial impact on RT agents' consumption. This in turn stabilizes aggregate demand, worked hours and wage inflation.

A labour disutility shock drives up wage inflation (Figure 4). This, in turn, stimulates consumption of RT agents. Optimizing consumers anticipate rising real interest rates and reduce their consumption. RT consumers' response dominates, and output increases on impact. This result is gradually reversed as real interest rate increases. Fiscal policy has negligible adverse effect on optimizing consumers and a substantial positive impact on RT consumers. Fiscal effects on price and wage inflation are modest, whereas we observe a beneficial effect on worked hours.

In concluding our discussion it is worth recalling the effect of fiscal stabilization rules on debt accumulation. For any shock, the debt feedback embedded in the fiscal rule was sufficient to dampen debt adjustment, which was of limited amplitude. Furthermore, in the case of technology and labour shocks, we observe a significant reduction in the volatility of nominal and real interest rates.

Two-country interactions. We now turn to analyse the interactions between the Union's two countries in the face of country-specific shocks. Before presenting our simulations, it is worth discussing the dynamic properties of the two-country model. As in Ferrero (2005), we apply Aoki's factorization (Aoki 1981) and focus on the national differences block, which is unaffected by the common monetary policy. Under the fiscal policy rules (8)-(9), determinacy requires a ceiling on the fiscal feedback on debt differences. Surprisingly, we find that a uniquely determined equilibrium obtains even if the fiscal feedback on debt differences falls to zero. This result is robust to an extensive sensitivity analysis on the parameter values of the model. For instance, it survives to changes in the degree of price and wage stickiness, it holds even in a simpler model where all consumers optimize, capital utilization and the capital stock are held constant at their steady state values, and the nominal

\footnotetext{
${ }^{11}$ This is due to its relatively limited weight on total labour costs.
} 
wage is flexible. It also survives to the introduction of asymmetries in the fiscal feedback coefficients. By contrast, under our baseline parameterization, the feedback on debt differences is not necessary as long as $\theta<0.65$. However, our result is consistent with a much larger share of RT consumers if the habit coefficient is reduced $(\theta<0.94$ if $b=0.4)$. While equilibrium determinacy requires that the share of forward-looking consumers does not fall below a certain threshold, it is consistent with a limited role for consumption risk sharing across the two economies, in line with reported empirical evidence about EMU. The reason why this happens can be understood by looking at consumption/saving decisions of optimizing households. In a monetary union, the latter determine output differentials, and thereby trigger fiscal stabilizers and the accumulation of debt differentials consistent with a unique equilibrium path.

This is an interesting and novel result. Combining the closed-economy and the national differences yields important implications for fiscal policy design. In order to ensure a stable and uniquely determined solution, it is sufficient that in each country the fiscal feedbacks react to the union-wide debt-to-GDP ratio. This obviously holds to the extent that fiscal rules entail a reaction to domestic output levels and forward-looking agents take such rules into account.

Asymmetric shocks. Once again, we consider the structural shocks outlined above, and analyze the four policy scenarios, "M", "M+G", "M+T" and "M+G+T". We show the impulse responses of a cost-push shock in the home country in Figure 5, including the impact on home country and foreign country variables. (As before the "M+G" case is not plotted to make the graphs clearer). For completeness, we also report the path for government debt in each country following the shock.

To save space, we do not show the impulse responses for all four shocks, and instead tabulate the impact of the different policy rules on the variance of output, consumer price and wage inflation, hours worked, as well as the consumption expenditure of optimising, RT consumers, and aggregate consumption. Variances are shown in Table 2.

As an example, in Figures 5-6 we show the dynamic response to a cost-push shock. The initial im-

\footnotetext{
${ }^{12}$ This is typical of New Keynesian models see, inter alia, Galí (2003).
} 
pact of a cost push shock on the domestic economy is to reduce output and wage inflation, and hence the consumption of RT consumers. The shock is transmitted positively to the foreign economy, mainly through the terms of trade appreciation, which boosts demand for foreign output and increases the consumption of RT consumers abroad. In both economies the biggest impact of fiscal policy is to stabilize consumption of RT households. This happens because national policies take opposite stances in the two countries: expansionary at home and contractionary abroad.

Turning to Table 2, showing the impact on the variances of the key variables under the remaining shocks, we see that the pattern outlined above is substantially repeated, but the role played by the fiscal instruments is shock-specific. In the home economy, fiscal rules always stabilize RT's consumption, wage inflation and worked hours. Their effect on optimizing consumers is sometimes adverse but negligible. The variance of consumer-price inflation slightly increases when fiscal rules are switched on. This pattern is substantially replicated for the foreign economy, therefore automatic stabilizers do not seem prone to generate conflicts between the national policymakers. However, we detect a potential conflict between the two consumers groups, because in some cases fiscal policy raises optimizing agents' consumption volatility.

\section{Sensitivity analysis}

We consider a number of variations in our model structural parameterization, under the baseline monetary policy rule. ${ }^{13}$ In particular we initially conduct a sensitivity analysis where parameters are changed symmetrically in both countries. Then we consider asymmetries between countries. In brief, although the stabilizing effect of fiscal policy is always appreciable, it becomes particularly large as the degree of habit persistence increases. In fact, without habit persistence, Ricardian agents can freely adjust consumption to variations in monetary policy (affecting the Union as a whole) and to changes in the terms of trade (affecting national differences).

\footnotetext{
${ }^{13}$ For robustness we also considered a battery of alternative specifications for the monetary policy rule. In particular: a forward-looking rule, a contemporaneous rule and a hybrid rule. Equilibrium determinacy conditions and the stabilizing performance of the fiscal rules extend to these cases. For further details, see the working paper version at http://dipeco.economia.unimib.it/persone/colciago/Wp.html.
} 
The performance of fiscal rules is not affected by increasing price stickiness, but tends to deteriorate following a rise in the average length of wage contracts. Finally, as expected, the effectiveness of automatic stabilizers decreases as the numerical importance of RT agents in the Union diminishes. Asymmetries between countries. We consider the possibility of asymmetric fiscal policies, by setting the output feedbacks in one country below the baseline value (alternatively: $\delta_{1}^{*}=\varphi_{1}^{*}=0.1$; $\delta_{1}=\varphi_{1}=0.1$. As a general pattern, the domestic effect of fiscal policy falls with the strength of the output feedback, but we cannot detect adverse consequences on the other economy. Similarly asymmetries in price-wage stickiness do not harm stabilization and do not generate inter-country conflicts. Finally, we consider asymmetric shares of RT agents. We set $\vartheta=0.3$ in the home country, while we keep the baseline value for the foreign country. As expected, fiscal policy constitutes a more desirable tool in the foreign country. However, in the case of a labour disutility shock the foreign country suffers higher volatility when fiscal stabilizers are active.

\section{Conclusions}

Our results may be summarized as follows. First, automatic stabilizers contribute to macroeconomic stabilization through their impact on disposable income of RT consumers. Second, while fiscal rules do not seem to generate inter-country conflicts, there are some within-country redistributive effects between RT and optimizing households. It is apparent that if one were to look at the utility of the two consumer groups, they would fare differently under different fiscal regimes. In general, a more active fiscal policy will tend to favour RT consumers who cannot actively participate in financial markets: in essence fiscal policy acts on their behalf. For Ricardian consumers fiscal stabilization policy can distort intertemporal consumptions choices. Third, our analysis of determinacy downplays the importance of controlling for the accumulation of national debt levels as opposed to the need of controlling the average debt-to-GDP ratio for the whole union. This is an important result, which runs counter to the philosophy of the Stability and Growth Pact which focuses on targeting national variables. However, it is subject to a caveat. In fact it crucially hinges on the national poli- 
cymakers' ability to commit national fiscal policies to simple feedbacks on national output levels. Absent such a commitment, a greater emphasis on tighter debt rules at national levels would obviously be justified. Further research should take into account distortionary taxation (beyond the payroll tax case discussed here) and the possibility of productive government spending. Moreover, it would be interesting to extend the potential role of fiscal policy by introducing Blanchard-Yaari optimizing consumers. Also, our model, as is standard practice in this literature, has focused on a symmetric model. In future research it would be interesting to relax this symmetry in a variety of dimensions, including a non-zero external position and differing degrees of openness.

\section{References}

Andres, J. and R. Domenech, (2005). “Automatic Stabilisers, Fiscal Rules and Macroeconomic Stability.", European Economic Review forthcoming.

Aoki, M. (1981). “Dynamic analysis of Open Economies”. New York: Academic Press.

Asdrubali, P., and Kim, S., (2005). "Incomplete Intertemporal Consumption Smoothing and Incomplete Risksharing,” International Finance 0506010, Economics Working Paper Archive EconWPA. Backus, D.K., P.J. Kehoe, and F.E. Kydland, (1994). "Dynamics of the trade balance and the terms of trade: The J-Curve?", American Economic Review, 84 (1) pages 84-103.

Beetsma and Debrun (2004), "The interaction between monetary and fiscal policies in a monetary union: a review of recent literature" in R. Beetsma, C. Favero, A. Missale, V.A. Muscatelli, P. Natale and P. Tirelli (eds.), "Fiscal Policies, Monetary Policies and Labour Markets. Key Aspects of European Macroeconomic Policies after Monetary Unification”. Cambridge University Press, Cambridge, United Kingdom.

Bilbiie, Florin O, (2005). "Limited Asset Market Participation, Monetary Policy, and Inverted Keynesian Logic," mimeo, Nuffield College, Oxford U.

Blanchard, O.J. and R. Perotti, (2002). "An empirical characterization of the dynamic effects of changes in government spending and taxes on output." Quarterly Journal of Economics, 117, 1329- 
68.

Buti, M., Franco D. and H. Ongena, (1998). "Fiscal Discipline and Flexibility in EMU: the Implementation of the Stability and Growth Pact", Oxford Review of Economic Policy, 14 (3): 81-97.

Buti, M., Roeger W. and in’t Veld, (2001)."Stabilizing Output and Inflation in EMU: Policy Conflicts and Cooperation under the Stability Pact". Journal of Common Market Studies, forthcoming. Campbell, J.Y. and Mankiw, N.G, (1989). "Consumption, Income, and Interest Rates: Reinterpreting the Time Series Evidence" in O.J. Blanchard and S. Fischer (eds.), NBER Macroeconomics Annual 1989, 185-216, MIT Press.

Canzoneri, M.B., Cumby, R. and Diba. B., (2002). "Should the European Central Bank and the Federal Reserve be concerned with Fiscal Policy? ", in Rethinking stabilization policies, Proceedings of the Symposium of the Federal reserve Bank of Kansas City, Jackson Hole, pp. 333-389.

Chari, V. V., Patrick J. Kehoe, and Ellen R. McGrattan, (2002). "Can Sticky Price Models Generate Volatile and Persistent Real Exchange Rates?.” Review of Economic Studies, 69 (3), 533-63.

Christiano, L.J., M. Eichenbaum, and C. Evans, (2005). "Nominal Rigidities and the Dynamic Effects of a Shock to Monetary Policy”. Journal of Political Economy vol. 113, no.1.

Colciago, A., (2006). "Rule of Thumb Consumers Meet Sticky Wages”. University of MilanoBiccoca WP series No 98.

Erceg, C.J., Levine, D. W., Levin, A., (2001). “Optimal Monetary Policy with Staggered wage and Price Contracts”. Journal of Monetary Economics, vol. 46(2), pp. 281-313.

Fatás, A. and I. Mihov, 2001. "Government size and automatic stabilizers: international and intranational evidence." Journal of International Economics, 55, 3-28.

Ferrero, A. (2005) "Fiscal and Monetary Rules for a Currency Union" ECB wp no 502 /July.

Galí, J., D. López-Salido, and J. Valles, (2004). "Rule-of- Thumb Consumers and the Design of Interest Rate Rules”, Journal of Money, Credit and Banking, Vol. 36 (4), August 2004, 739-764.

Galí, J. (2003). "New perspectives on monetary policy, inflation, and the business cycle”. In M. Dewatripont, L. Hansen, and S. Turnovsky (Eds.), Advances in Economic Theory, pp. 151-197. 
Cambridge University Press.

Galí, J., D. López-Salido, and J. Valles, (2007). "Understanding the Effects of Government Spending on Consumption", Journal of the European Economic Association, vol. 5 (1), pp. 227-270.

Galí, J. and Monacelli, T. (2005) "Optimal Monetary and Fiscal Policy in a Currency Union" mimeo downloadable from http://www.econ.upf.edu/crei/ people/gali/pdf_files/gm05mu.pdf

Kalemli-Ozcan, Sebnem Sorensen, Bent E Yosha, Oved, (2004) “Asymmetric Shocks and Risk Sharing in a Monetary Union: Updated Evidence and Policy Implications for Europe" CEPR discussion paper No 4463.

Muscatelli, A., P. Tirelli and C. Trecroci, (2003a). "The Interaction of Fiscal and Monetary Policies: Some Evidence using Structural Models.", CESifo Working Paper n.1060, forthcoming, Journal of Macroeconomics.

Muscatelli, A., P. Tirelli and C. Trecroci, (2003b). "Can fiscal policy help macroeconomic stabilization? Evidence from a New Keynesian model with liquidity constraints", CESifo Working Paper, n.1171.

Muscatelli, V.A., P. Tirelli and C. Trecroci, (2004). ”Monetary and fiscal policy interactions over the cycle: some empirical evidence", in R. Beetsma et al. (eds) op. cit.

Muscatelli, V.A., T. Ropele and P. Tirelli (2005) "Macroeconomic Adjustment in the Euro-area: The Role of Fiscal Policy" mimeo.

Sarantis, N and Stewart, C, (2003) "Constraints, Precautionary Saving and Aggregate Consumption: an International Comparison " Economic Modelling, 20 (6), 1151-1174

Schmitt-Grohé, S., and M. Uribe, (2005). "Optimal Fiscal and Monetary Policy in a Medium-Scale Macroeconomic Model: Expanded Version”. NBER Working Paper No. 11417.

Van den Noord, P. (2000). "The Size and Role of Automatic Fiscal Stabilizers in the 1990s and Beyond". OECD Working Paper, ECO/WKP 2000 (3). 


\section{Tables}

\begin{tabular}{ccl}
\hline \hline Parameter & Value & Description \\
\hline$\beta$ & 0.9926 & subjective discount factor \\
$\vartheta$ & 0.5 & share of non Ricardian consumers \\
$\delta$ & 0.36 & share of capital \\
$\theta_{w}$ & 0.025 & depreciation rate \\
$\eta$ & 21 & wage-elasticity of demand for a specific labor variety \\
$\theta_{p}$ & 6 & elasticity of substitution between $\mathrm{C}_{H}$ and $\mathrm{C}_{F}$ \\
$\chi$ & 0.7 & home bias \\
$\xi_{p}$ & 0.75 & probability of keeping prices fixed in a given period \\
$\xi_{w}$ & 0.75 & probability of keeping wages fixed in a given period \\
$b$ & 0.65 & degree of habit persistence \\
$\varphi$ & 1 & preference parameter \\
$\kappa$ & 0.248 & investment adjustment costs \\
$\gamma_{1}$ & 0.0324 & parameter governing capacity adjustment costs \\
$\gamma_{2}$ & 0.000324 & parameter governing capacity adjustment costs \\
$\frac{G}{Y}$ & 0.2 & share of government purchase \\
$\frac{D}{Y}$ & 0.6 & steady state debt-to-GDP ratio \\
$\phi_{1}$ & 0.5 & monetary policy response to exp. inflation \\
$\phi_{2}$ & 0.05 & monetary policy response to output gap \\
$\phi_{3}$ & 0.8 & parameter governing interest rate inertia \\
$\delta_{2}=\varphi_{1}$ & 0.5 & fiscal response to output gap \\
\hline \hline & 0.05 & fiscal response to accumulated debt \\
\hline & &
\end{tabular}




\begin{tabular}{|c|c|c|c|c|c|c|c|c|}
\hline \multicolumn{9}{|c|}{ RELATIVE VARIANCES } \\
\hline \multicolumn{9}{|c|}{ Cost push shock } \\
\hline & Rule & $C^{o}$ & $C^{r t}$ & $C$ & $h$ & $Y$ & $\pi$ & $\pi^{w}$ \\
\hline \multirow{3}{*}{ Country $H$} & $G / M$ & 0.68 & 0.78 & 0.78 & 0.73 & 0.72 & 1.20 & 0.7 \\
\hline & $T / M$ & 0.85 & 0.80 & 0.79 & 0.91 & 0.91 & 1.06 & 0.79 \\
\hline & $(G+T) / M$ & 0.59 & 0.62 & 0.62 & 0.66 & 0.67 & 1.29 & 0.56 \\
\hline \multirow{3}{*}{ Country F } & $G / M$ & 2.33 & 0.49 & 0.49 & 0.46 & 0.46 & 0.94 & 0.47 \\
\hline & $T / M$ & 1.02 & 0.68 & 0.68 & 0.81 & 0.80 & 1.05 & 0.71 \\
\hline & $(G+T) / M$ & 4.39 & 0.33 & 0.33 & 0.37 & 0.36 & 0.92 & 0.33 \\
\hline \multicolumn{9}{|c|}{ Demand Shock } \\
\hline \multirow{3}{*}{ Country $H$} & $G / M$ & 1.03 & 0.57 & 0.84 & 0.64 & 0.65 & 1.86 & 1.63 \\
\hline & $T / M$ & 1.00 & 0.49 & 0.81 & 0.73 & 0.74 & 1.69 & 1.46 \\
\hline & $(G+T) / M$ & 1.05 & 0.42 & 0.78 & 0.62 & 0.63 & 2.07 & 1.73 \\
\hline \multirow{3}{*}{ Country $F$} & $G / M$ & 0.99 & 0.28 & 0.68 & 0.28 & 0.29 & 0.54 & 0.26 \\
\hline & $T / M$ & 0.99 & 0.39 & 0.73 & 0.48 & 0.49 & 0.62 & 0.39 \\
\hline & $(G+T) / M$ & 1.00 & 0.18 & 0.67 & 0.22 & 0.22 & 0.52 & 0.17 \\
\hline \multicolumn{9}{|c|}{ Labor shock } \\
\hline \multirow{3}{*}{ Country $H$} & $G / M$ & 1.15 & 0.71 & 0.77 & 0.67 & 0.71 & 1.27 & 0.83 \\
\hline & $T / M$ & 0.98 & 0.81 & 0.79 & 0.91 & 0.92 & 1.23 & 0.93 \\
\hline & $(G+T) / M$ & 1.21 & 0.55 & 0.63 & 0.62 & 0.66 & 1.34 & 0.74 \\
\hline \multirow{3}{*}{ Country F } & $G / M$ & 0.65 & 0.69 & 0.69 & 0.63 & 0.62 & 0.79 & 0.63 \\
\hline & $T / M$ & 0.72 & 0.83 & 0.83 & 0.95 & 0.95 & 0.89 & 0.82 \\
\hline & $(G+T) / M$ & 1.15 & 0.53 & 0.52 & 0.55 & 0.53 & 0.77 & 0.49 \\
\hline \multicolumn{9}{|c|}{ Technology shock } \\
\hline \multirow{3}{*}{ Country $H$} & $G / M$ & 1.73 & 0.52 & 0.54 & 0.53 & 0.46 & 0.73 & 0.47 \\
\hline & $T / M$ & 1.50 & 0.61 & 0.63 & 0.73 & 0.70 & 0.74 & 0.60 \\
\hline & $(G+T) / M$ & 1.91 & 0.39 & 0.42 & 0.47 & 0.39 & 0.75 & 0.36 \\
\hline \multirow{3}{*}{ Country F } & $G / M$ & 0.61 & 0.30 & 0.31 & 0.25 & 0.25 & 0.83 & 0.41 \\
\hline & $T / M$ & 0.61 & 0.42 & 0.42 & 0.46 & 0.46 & 0.99 & 0.55 \\
\hline & $(G+T) / M$ & 0.64 & 0.20 & 0.22 & 0.19 & 0.19 & 0.75 & 0.30 \\
\hline
\end{tabular}


Figures
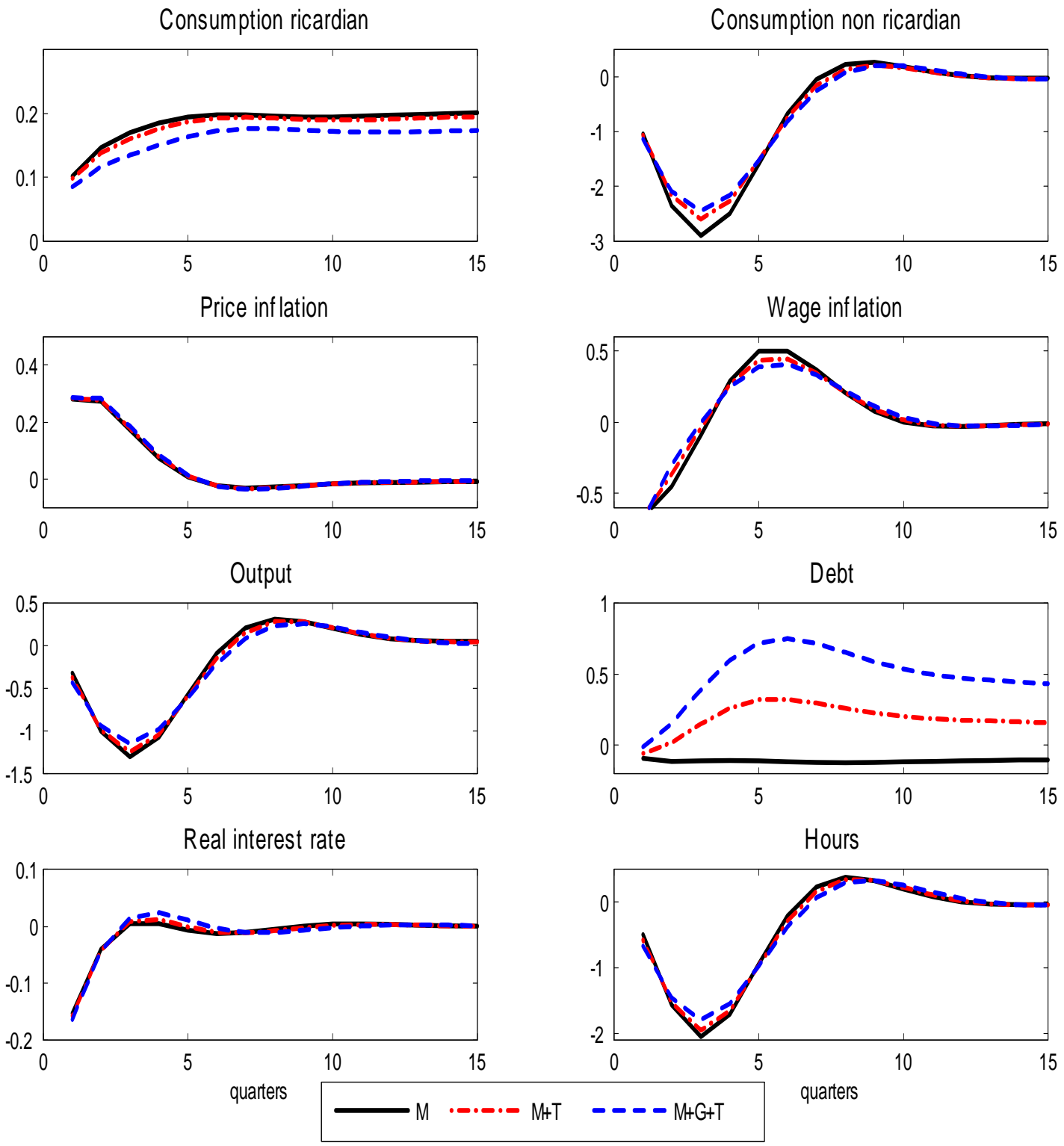

Figure 1: Response of key variables to a cost push shock when the Union is regarded as a single coutry. 

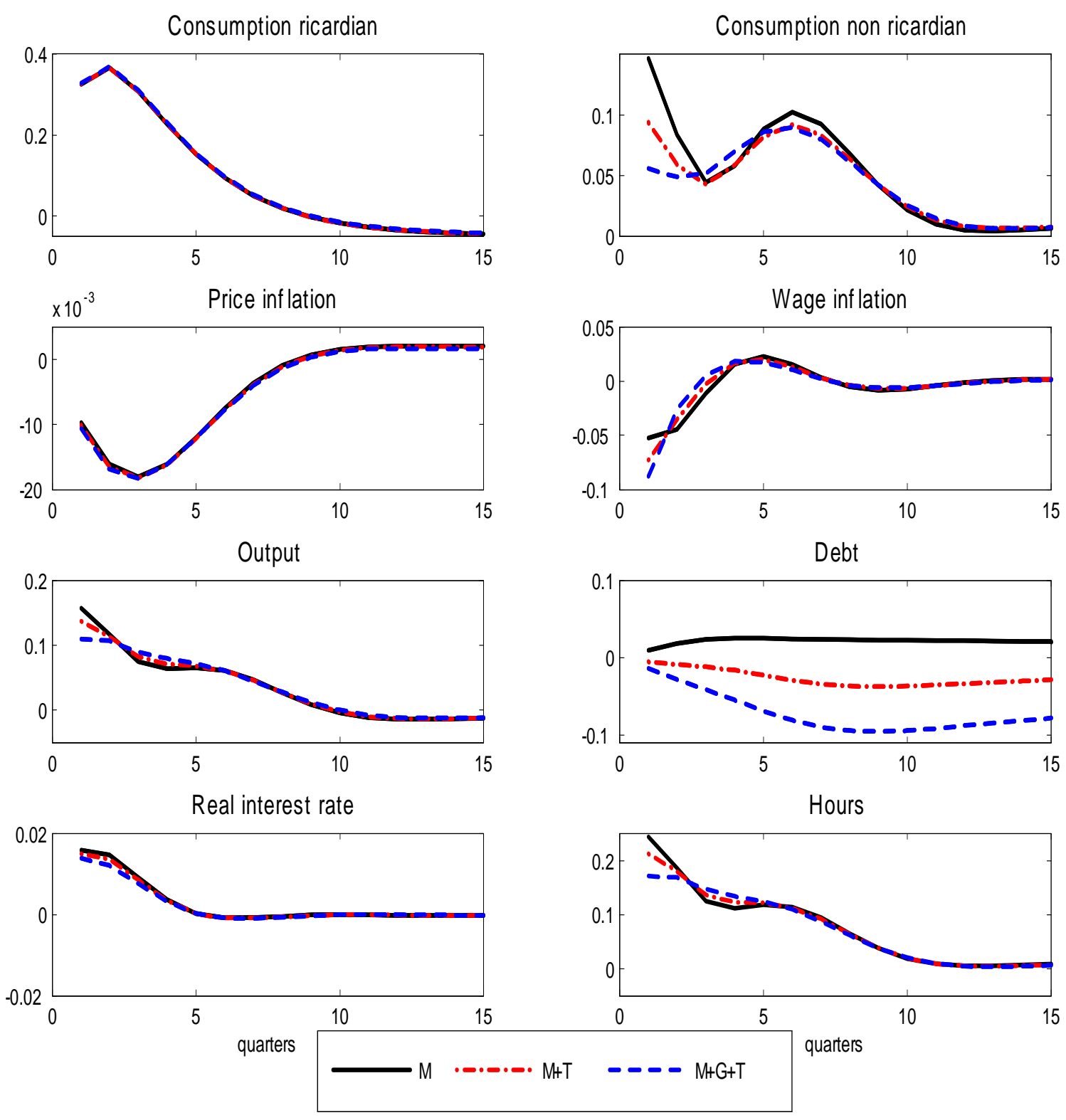

Figure 2: Response of key variables to consumption preference shock when the Union is regarded as a single country. 

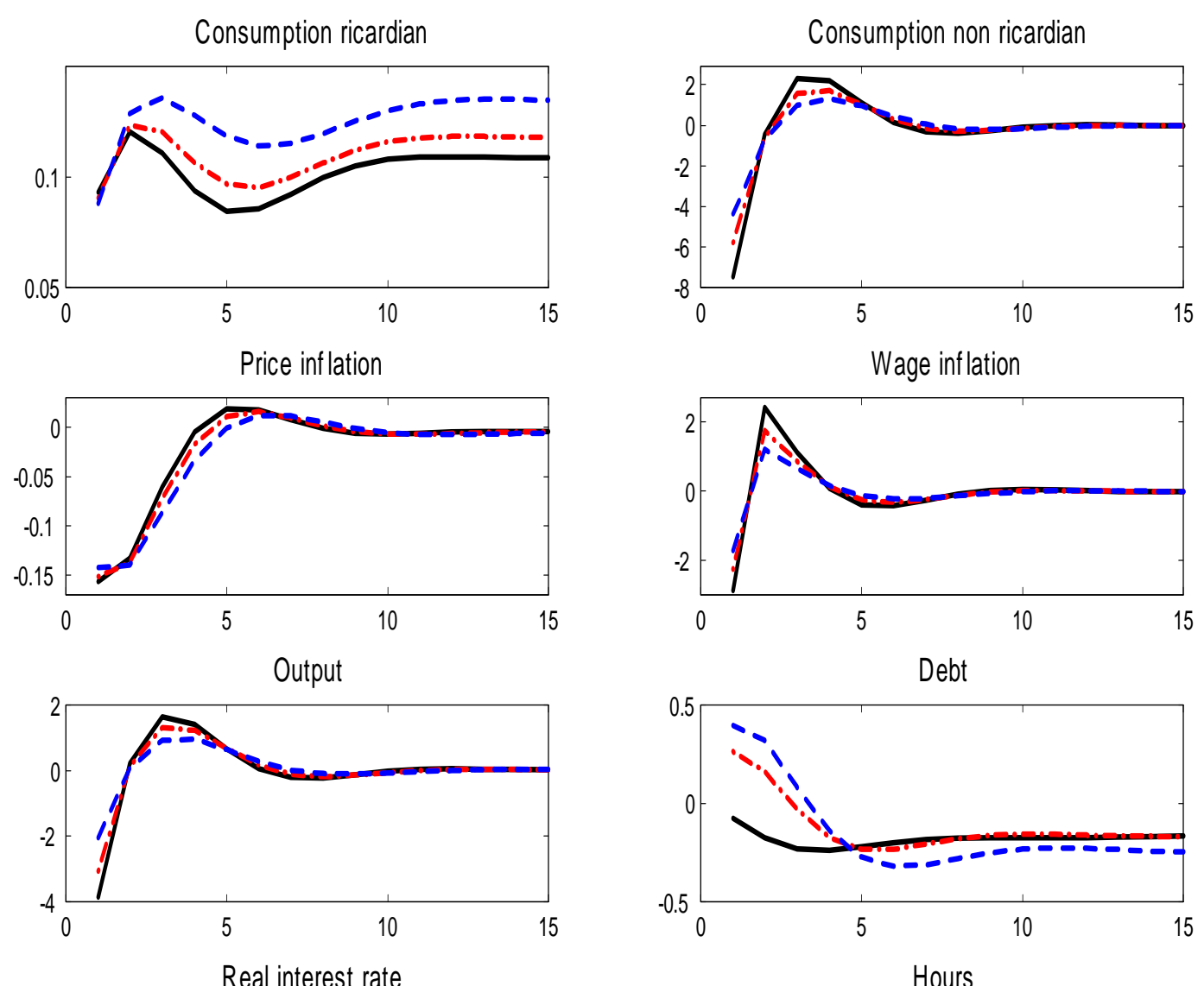

Real interest rate

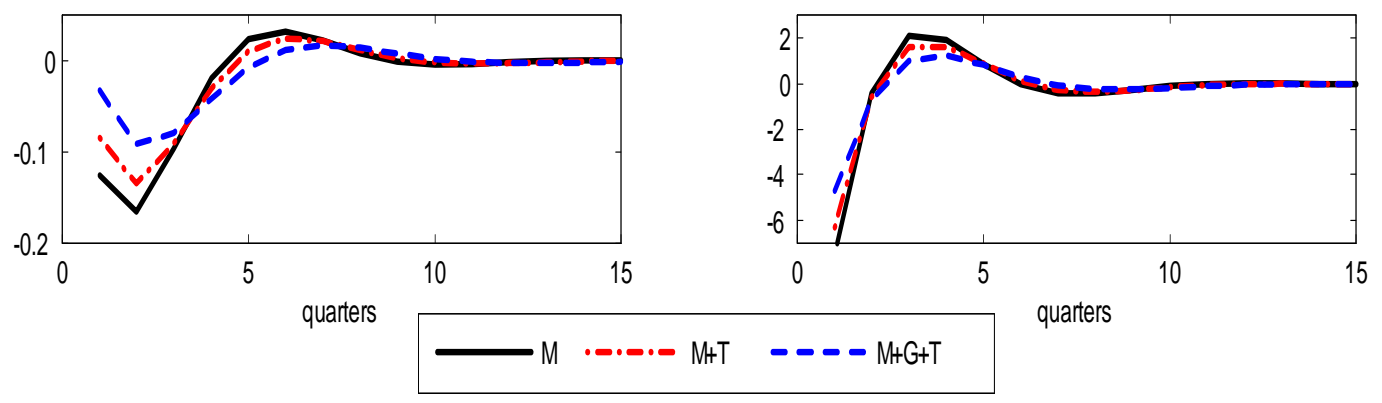

Figure 3: Response of key variables to a technology shock when the Union is regarded as a single country. 

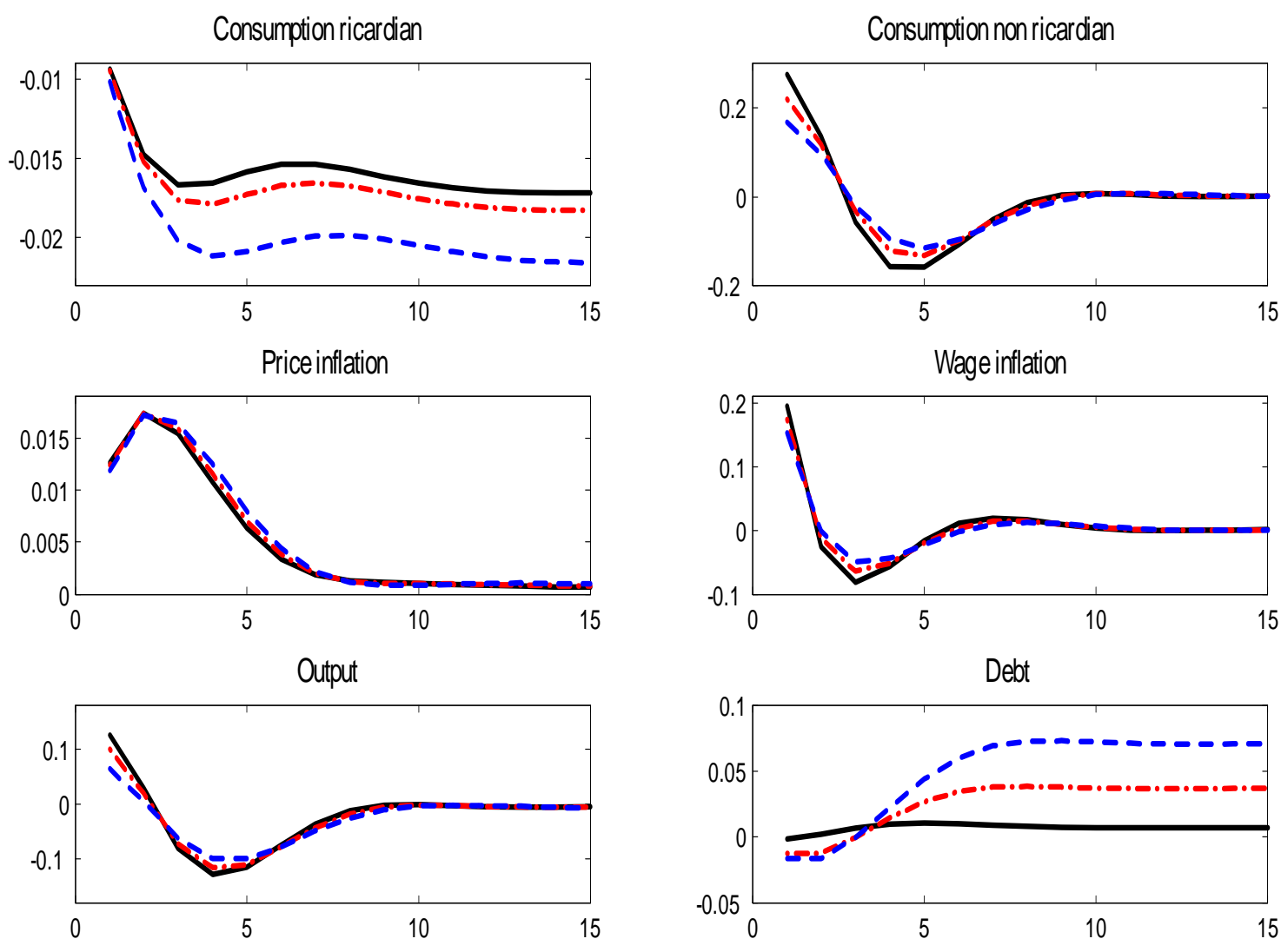

Real interest rate

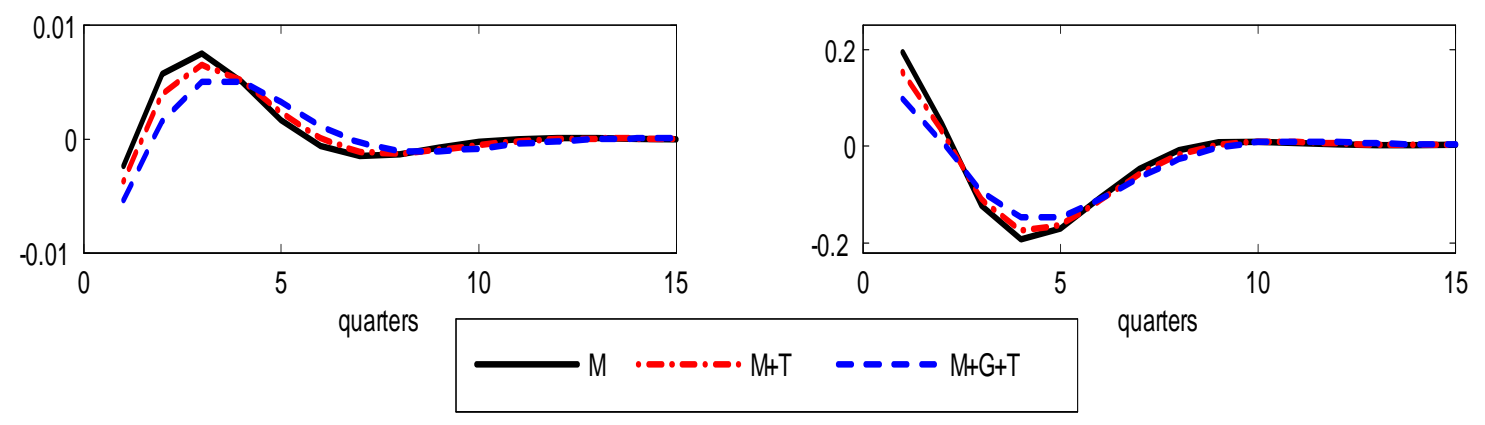

Figure 4: Response of key Variables to a labour disutility shock when the union is regarded as a single country. 

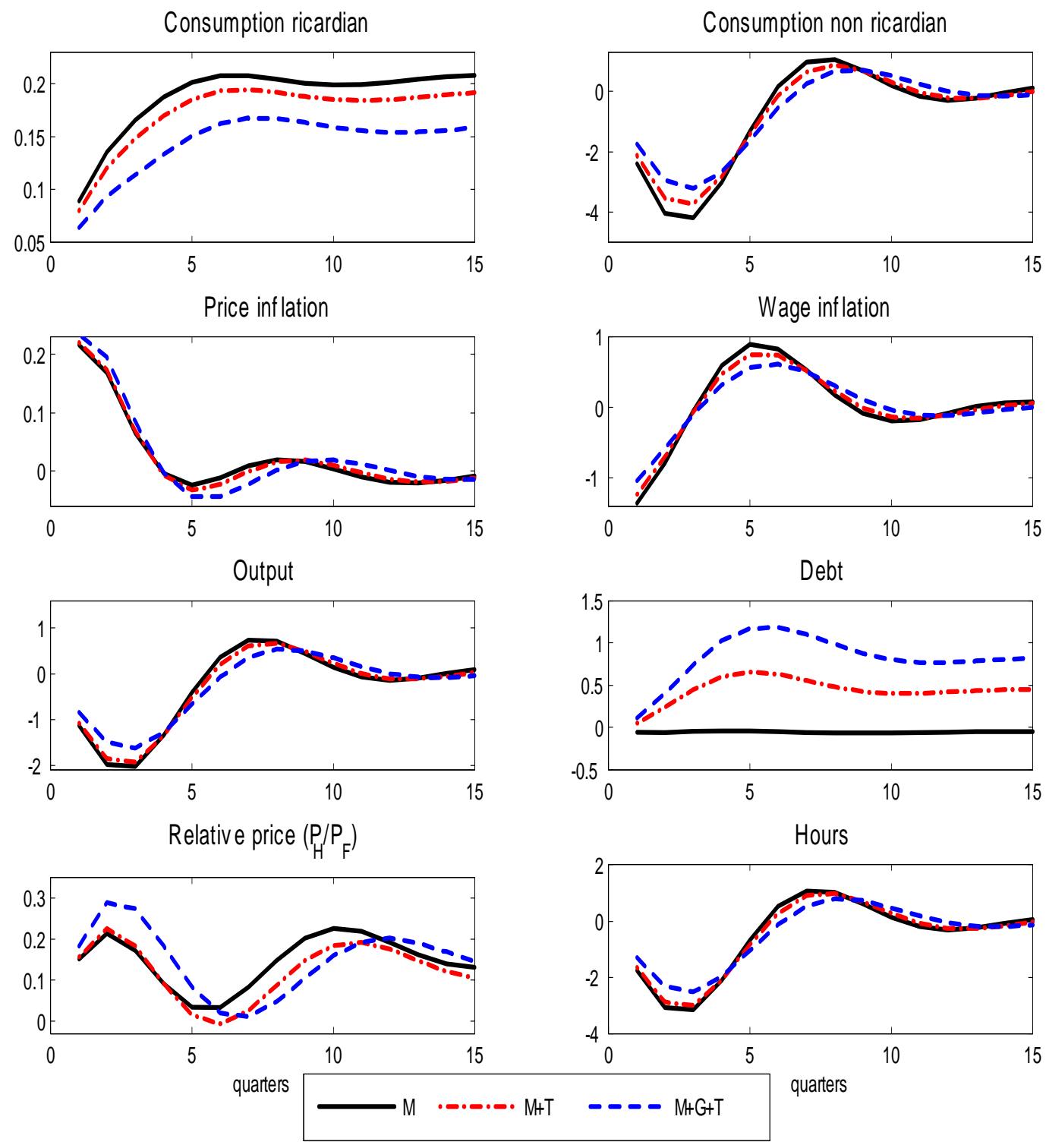

Figure 5: Response of domestic variables to a cost push shock 

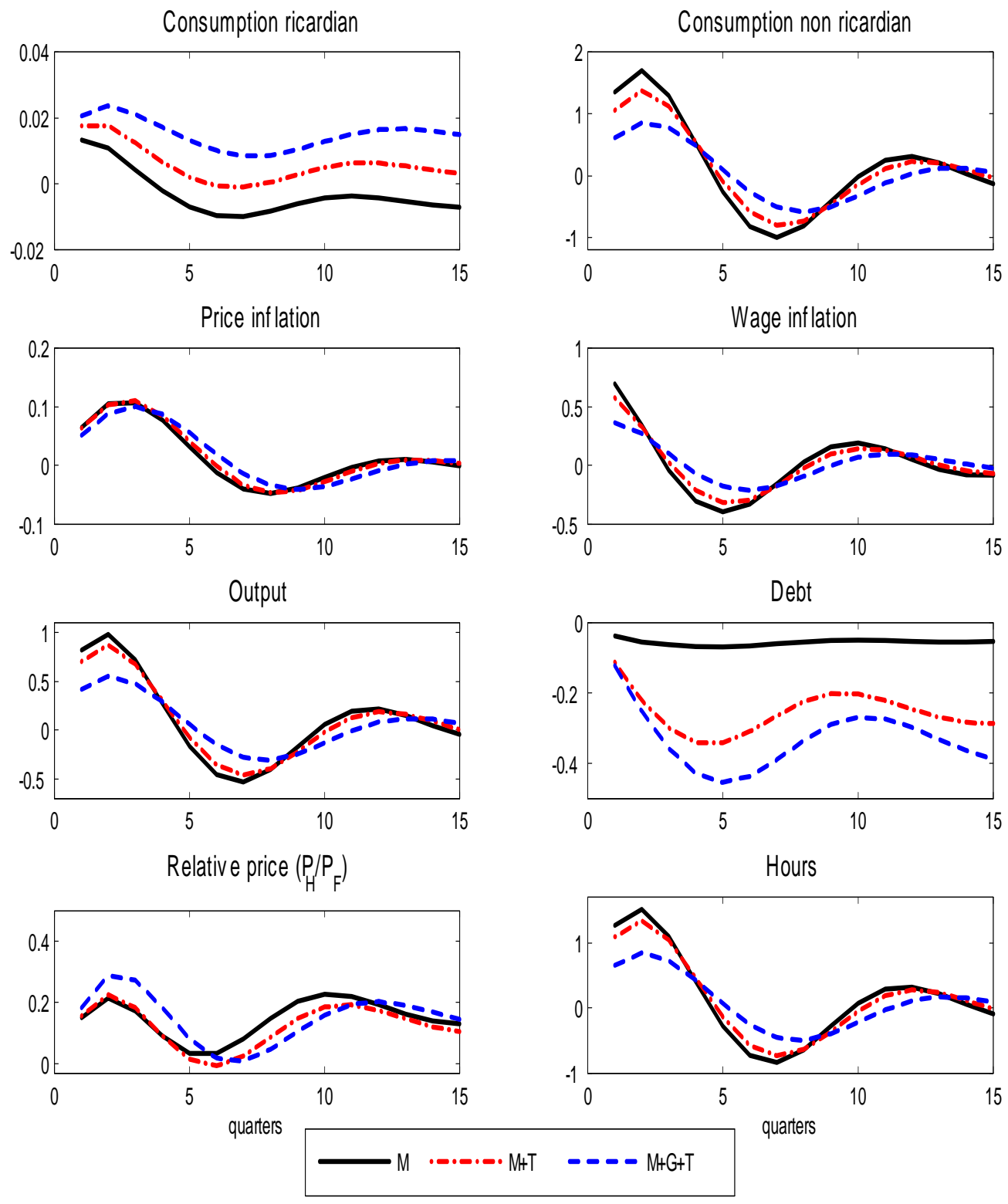

Figure 6: Response of foreign variables to a cost push shock in country $\mathrm{H}$. 